\title{
Origin and protection of middle-European bees in Europe
}

\author{
BEATA MADRAS-MAJEWSKA, ŁUCJA SKONIECZNA \\ Apiculture Division, Faculty of Animal Sciences, Warsaw University of Life Sciences - SGGW, \\ Nowoursynowska 166, 02-787 Warszawa, Poland
}

Madras-Majewska B., Skonieczna $\leftarrow$.

\section{Origin and protection of middle-European bees in Europe}

\section{Summary}

The population of the honey bee, Apis mellifera, continues to shrink. The middle-European bee, Apis $m$. mellifera, is particularly at risk in Europe. The drop in the number of middle-European bees is so huge that the insect is under the threat of extinction. Today, they live on small areas covered by the protection of genetic resources. Apis m. mellifera is protected mainly in areas where this species evolved: for instance, in Switzerland, Latvia, Norway, Sweden, Finland, Denmark, France, Germany, Poland or Russia. This paper presents methods used to preserve and protect Apis m. mellifera in Europe and research on the descent and original extent of the species. It also reviews opportunities created by the implementation of various types of programs for the protection of genetic resources of Apis $\mathbf{m}$. mellifera and ways of employing morphological and genetic studies for the conservative breeding of middle-European bees. The paper demonstrates that the protection of Apis $m$. mellifera in Europe is necessary, considering the decreasing size, and the threat of hybridization, of this population. The use of the morphometric evaluation and DNA analysis methods have made it possible to track and compare likely directions of propagation of genes in the long history of evolution of bees. Moreover, these methods have given us better insight into the ongoing processes. The current use of these methods for reliable identification of bee breeds helps to protect Apis m. mellifera more effectively. European programs for the protection of genetic resources of bees are based on the following two main paradigms: the breeding of local isolated populations on islands and establishment of protected inland areas for the conservative breeding of contained swarms. All these programs share and are successful in achieving the goal that consists in the preservation of the characteristics of Apis $\mathrm{m}$. mellifera as unchanged as possible, with retention of the maximum genetic diversity of the species.

Keywords: native middle-European, bee protection program, morphological studies, genetic studies

The honey bee, as a pollinator, is a very important part of ecosystems, ensuring survival of many species of plants and animals. However, adverse anthropogenic changes in ecosystems lead to deterioration of the environment, depletion of the mix of species of animals and plants and an elongation of the list of breeds threatened with extinction or already dying out. One of the main threats today is the drop in the size of bee populations in broadly defined taxonomic and geographic terms (40). The key contributors to the problem include extensive exploitation of the natural environment, depletion of melliferous plant breeds, monocultures, parasites and pathogens, as well as genetic isolation leading to inbreeding $(10,66)$. The middle-European Apis $m$. mellifera is particularly at risk. The massive introduction of queens of other sub-species to apiaries for profit was another important factor that has caused the drastic drop in the size of populations of this native middle-European bee. Beekeepers who were aiming at profits replaced Apis m. mellifera queens with more efficient Carniolan Apis m. carnica or Caucasian Apis m. caucasica specimens for a better honey yield. As a result, middle-European bees have been almost entirely displaced from their natural habitats. Today they exist on small protected areas in Switzerland, Latvia, Norway, Sweden, Finland, Denmark, France, Germany, Poland or Russia.

Relatively early Europe has taken efforts to keep bee features characteristic for Apis m. mellifera possibly unchanged, with retention of maximum genetic diversity of the species. The first areas of conservative breeding in Poland were established in the 1970s and 1980s, mainly in the national parks of the Augustów Backwoods and the Kampinos Backwoods. Today, 
middle-European bees are protected mainly in regions where this species evolved. European countries pursue three types of programs for protection of genetic resources of Apis m. mellifera (53):

1) breeding of local populations on islands providing physical isolation, such as La Palma (the Canary Islands), the Azores, Madeira or the Danish isle of Laeso;

2) the maintainenance of contained conservative swarms, for instance in France and England;

3 ) the establishment of protected inland areas, such as in Austria, Switzerland or Scandinavia (22).

The employment of morphological methods for describing middle-European bee populations makes it possible to compare various breeds and to identify phylogenetic links and directions of the expansion of these insects $(50,53)$. On the other hand, the DNA analysis enables verification of the affiliation of honey bee populations with individual sub-species or evolutionary lines; i.e. tracking of directions of propagation of genes during the historical evolution of the species (16). Now these methods are becoming increasingly popular as tools for protection of populations of Apis m. mellifera.

This paper presents methods used to preserve and protect Apis m. mellifera in Europe and research on the descent and original extent of the species. It also reviews opportunities created by the implementation of various types of programs for protection of genetic resources of Apis m. mellifera and ways of employing morphological and genetic studies for conservative breeding of middle-European bees.

\section{Historical background}

Origin of Apis m. mellifera according to research. Systematization of Apis genus and Apis mellifera species is not an easy task because researchers report different numbers of breeds of these insects. Engel compiled a list of breeds of both living and extinct bees (18), identifying 178 breeds and 10 gene groups. According to the author, bees came into existence in the Indo-Malaysian region in early the Oligocene. The migration of these insects (native to Europe, Africa and south-eastern Asia) from Asia was constrained by the cooling of the climate. Accommodation of at least two species - Apis cerana and Apis mellifera - to these conditions in the early Pliocene (the building of covered nests) enabled the bees to spread. Apis mellifera inhabited Europe and north-western Asia and Apis cerana migrated to north-eastern China and to eastern parts of the former Soviet Union. Other researchers drew different conclusions about the number of bee breeds: (11) identified three, $(1,26)$ four, and (36) as many as twenty four breeds. Later on, nine breeds of Apis mellifera (64) were distinguished. Considering the extent of their spread, behaviors and morphological features, subspecies or geographic breeds of Apis mellifera can be divided into four groups (65):

- Group 1: dark-colored bees from northern and western Europe and from northern Africa: Apis $m$. mellifera, Apis m. iberica, Apis m. major, Apis m. intermissa, Apis m. sahariensis;

- Group 2: Balkan bees and their relatives defined (50) as "a group of Carniolan bees": Apis m. carnica, Apis m. macedonica, Apis m. cecropia, Apis m. ligustica, Apis m. sicula (40);

- Group 3: Oriental bees: Apis m. caucasica, Apis m. armenica, Apis m. meda, Apis m. anatolica, Apis m. syriaca, Apis m. cypria, Apis m. adami;

- Group 4: African bees: Apis m. lamarckii, Apis m. fasciata, Apis m. jementica, Apis m. litorea, Apis m. scutellata, Apis m. monticola, Apis m. adansoni, Apis m. unicolor, Apis m. capensis.

The extent of the natural spread of Apis m. mellifera sub-species from group 1 includes regions from Spain and France, through Scandinavia, Germany, Poland, up to the Ural Mountains $(16,18,29,50,52)$. The subspecies came to existence in the late Pleistocene, 8-10 thousand years ago (49). A comparison of populations of contemporary bees to their fossil ancestors gives an insight into their phylogenesis. Researchers have examined bees from the Oligocene, Miocene and PlioPleistocene. The oldest fossil bees (relatives of Apis), living in the Cretaceous, were discovered in China (18). No specimens were found older than those from the

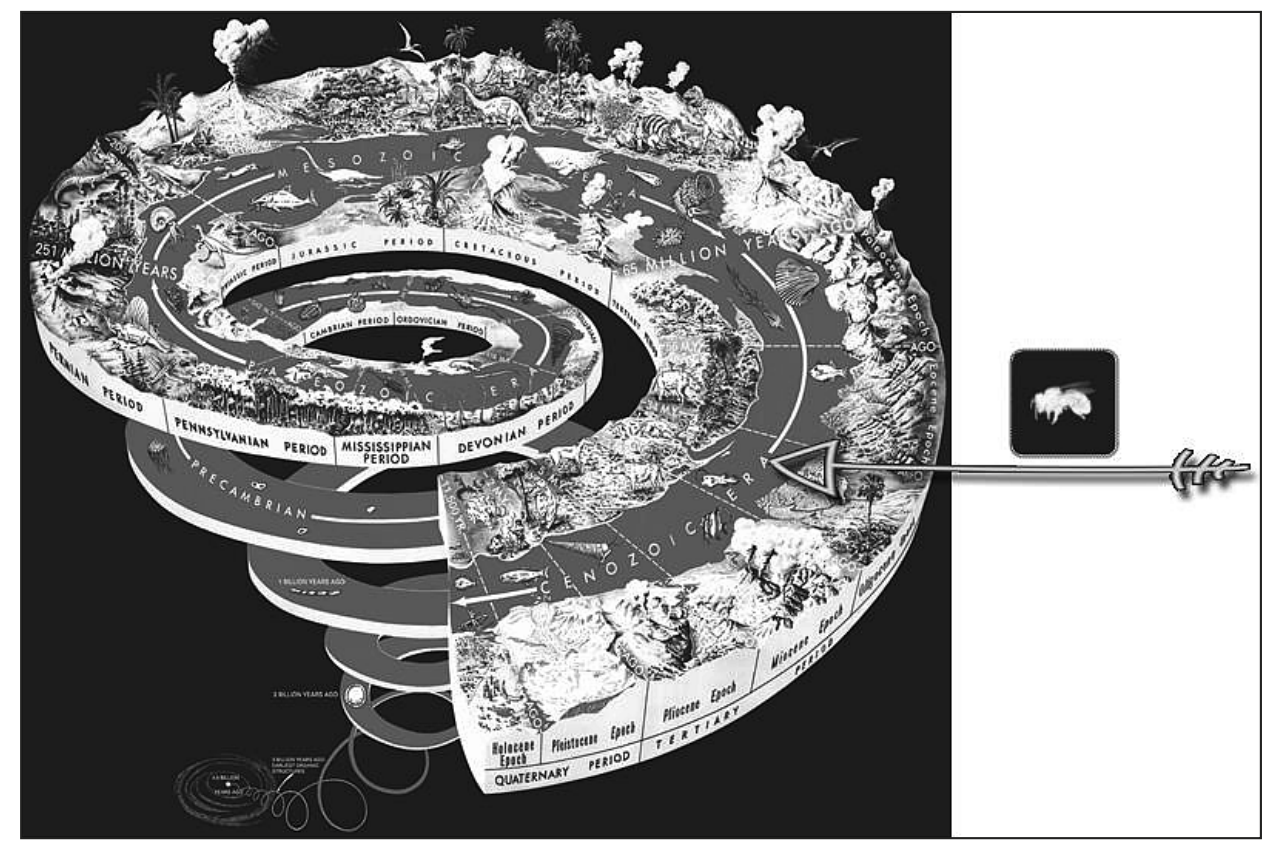

Fig. 1. Stratigraphic clockwise spiral showing the passage of time. The arrow points at the time of appearance of bees 


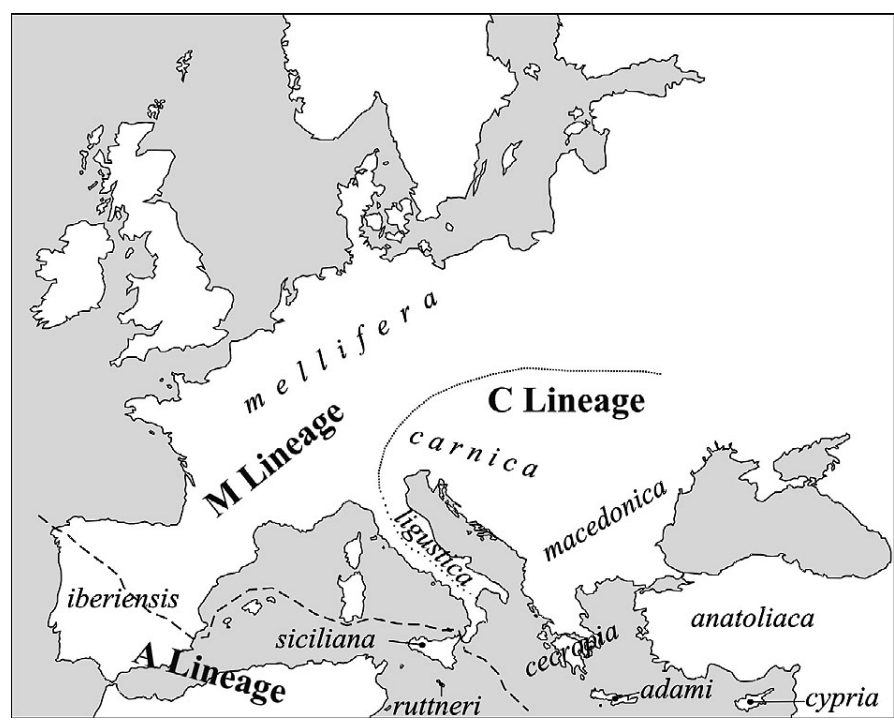

Fig. 2. Approximate natural spread of evolutionary lines and sub-species of Apis mellifera in Europe (53): A - mainly African sub-species; $M$ - west-European "mellifera"; $C$ - eastern and south Alpine and north-Mediterranean "carnica"

Oligocene: i.e. older than 34-28 million years $(18,33)$. The moment of appearance of bees in the history of the Earth is according to the dating of the oldest fossil bees (Fig. 1). This description of bees based on statistical analyses of their morphology enabled the comparison of the bees for the identification of their phylogenetic links and directions of spreading.

The analysis shows that variability of features such as body and wing sizes are correlated more strongly with geographic locations than with vein patterns associated with phylogenetics $(16,50,53)$. Research based on morphological measurements of forty two features (50) has identified features of Apis mellifera species and this identification revealed the existence of three and finally four initial evolutionary branches. Moreover, the geometric morphometry identified four phylogenetic lines (A - mainly African sub-species; $\mathrm{M}$ - west-European "mellifera"; $\mathrm{C}$ - eastern and south Alpine and north-Mediterranean "carnica"; $\mathrm{O}$ - "oriental" sub-species from the eastern peripheries of the spread of the species) and enabled repeated verification of the division and an update of the classification of honey bees into distinct sub-species $(32,55)$. The revised classification of honey bees showed that features of Apis m. intermissa (hitherto included in line $\mathrm{M}$ ), Apis m. sicula (C), Apis m. sahariensis (M) and Apis m. syriaca $(\mathrm{O})$ are more similar to those of line $\mathrm{A}$. The distribution of phylogenetic lines and sub-species of Apis mellifera in Europe are presented on Fig. 2 (53).

DNA analyses of various molecular markers indicate that Apis m. mellifera domes from the regions of distribution of phylogenetic line $\mathrm{O}$ or from adjacent regions that are presently inhabited by Apis m. lamarkii (from Egypt and Somalia), Apis m. meda (from Turkey) and Apis m. macedonica (from Greece), where the split into evolutionary lines $\mathrm{M}$ and $\mathrm{C}$ is most likely to have taken place (16).

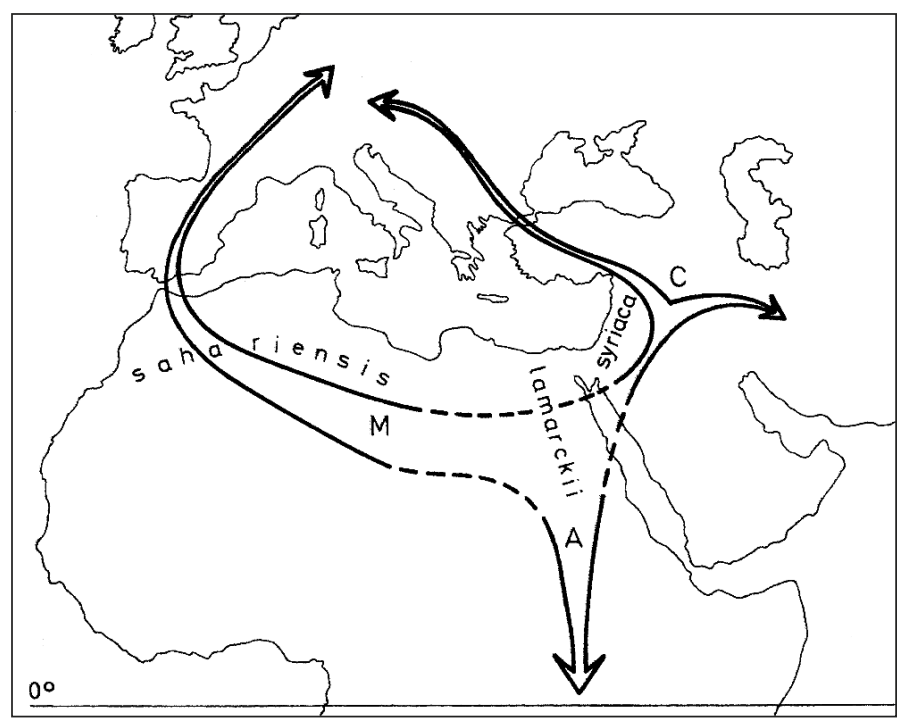

Fig. 3. Three main phylogenetic branches $(A, C, M)$ of the morphogenetic evolution of the breeds of Apis mellifera species (50)

Morphometric studies carried out in the 1930s and 1940 s accurately established the region of occurrence of the middle-European bee. The initial spread of Apis m. mellifera following its expansion after the last glaciation covered a wide and tall stretch of Europe: from the Iberian Mountains in the west to the Ural Mountains in the east and from the Alps and the Carpathians in the south to the British Isles, Finland, Sweden, Norway and the Polar Circle in the north. The glacial period that lasted from approx. 130 thousand years ago until about 10 thousand years ago displaced climatic conditions supporting the insect life far to the south. Mean temperatures in southern Europe were close to the present temperatures of the central and northern parts of the continent and isolated areas free from ice cover sheltered various bee species (59). The high homozygosity of Apis m. mellifera seems to confirm the existence of such enclaves (19). The Iberian Peninsula was such an enclave for middle-European bees (39); Italian bees survived the glaciation on the Apennine Penninsula (20); while other research (38) found a similar enclave on the Balkan Peninsula. The spread and evolution of bees were strongly affected by climatic cycles of subsequent glaciations and interglacial periods. The Mediterranean region developed three main genetic lines as a result of isolation of breeds on the three peninsulas. In addition, the Pyrenees and Alps acted as barriers to migrations (54).

Ruttner (50) has drawn three phylogenetic lines of honey bees and the likely routes of propagation of genes while this species spread out onto an increasingly larger stretch of land (Fig. 3). This suggests that Apis mellifera had common ancestors on the African continent. Some researchers indicate regions other than Africa as places of origin of the honey bee: (15) looks at the Middle East, (23) identifies the origin of Apis species with the Caspian Sea region and dates its coming to existence to a period from 300 thousand to 1.3 million years ago, long before the glaciation. Moreover, (51) 
indicates a region between the Mediterranean and the Caspian seas, which seems to be a better substantiated theory in the light of the research (5) suggesting a much earlier that hitherto estimated date of the split into Apis mellifera and Apis cerana (approx. 1-2 million years ago) (49). In addition, middle-European bees show much stronger affinity to Asian than to African bees $(5,49)$. Many authors acknowledged the south-eastern origin of the middle-European bee $(16,21,49)$.

\section{Characteristics of Apis m. mellifera based on morphological studies}

Vaguely defined size and color were used for differentiation of European bees until the beginning of the $20^{\text {th }}$ century. Bees with yellow abdomens were classified as "Italian" regardless of the location of their occurrence: for instance, in central Europe, northern Africa and on Rhodes (50). This changed in time with development of more accurate criteria for defining and describing various breeds $(1-3,26)$. Considering the lack of barriers to reproduction between European and African populations and based on complex statistical analyses of morphological features, these breeds are recognized as a single species. Thee analyses enabled the identification of sub-species or breeds of the honey bee, as well as a determination of the geographical extent of their habitats $(13,50)$. Researchers describing various populations of bees noted that sizes of bee body parts depend on latitude. One of the scientists observed a $0.81 \mathrm{~mm}$ difference in the length of proboscis between the $45^{\text {th }}$ and the $60^{\text {th }}$ degrees of northern latitude (3). Similar dependences were found for European bees (26) and for the length of the proboscis and hind leg in west-European black bees (51). Also (52) described local populations of Apis m. mellifera based on selected morphometric features depending on latitude (Tab. 1). In addition, (52) identified the historical spread of middle-European bees in Europe based on results of morphometric studies. On the other hand, comparison of samples from these studies (52) to samples taken from the British Museum, dated to the $19^{\text {th }}$ century, and derived from excavations from the $10^{\text {th }}$ century (a Viking settlement in York) and from the $12^{\text {th }}$ century (from around Oslo) substantiates the claim that the middle-European bee has not evolved much over the last millennium.

In time, those of the known morphological features used to characterize various populations of bees that were less important from the point of view of discrimi-

Tab. 1. Comparison of the features of a few populations of black bees (52)

\begin{tabular}{|l|c|c|c|c|c|}
\hline \multicolumn{1}{|c|}{ Region } & Latitude & $\begin{array}{c}\text { Sample size } \\
\text { N }\end{array}$ & $\begin{array}{c}\text { Tergites } \\
3+4\end{array}$ & $\begin{array}{c}\text { Forewing length } \\
{[\mathrm{mm}]}\end{array}$ & $\begin{array}{c}\text { Proboscis length } \\
{[\mathrm{mm}]}\end{array}$ \\
\hline Provence, S. France & 44 & 3 & 4.537 & 9.231 & 6.265 \\
Yorkshire & 54 & 6 & 4.667 & 9.346 & 6.013 \\
\hline Isle of Man & 54 & 4 & 4.642 & 9.380 & 6.008 \\
\hline Norway & $58-60$ & 23 & 4.684 & 9.383 & 5.962 \\
\hline
\end{tabular}

native effectiveness and, at the same, more time-consuming in execution, or ones that failed to contribute significant information after inclusion in analysis, got to be omitted. The characteristics of European and eastern breeds are based on 10 morphological features (51). Finally, after a discriminatory analysis, researchers decided to select breeding material based on values of three discriminatory parameters: the length of proboscis, the sum of widths of abdominal tergites 3 and 4 and the cubital index (13).

Morphological measurement methods were gradually improved. Measuring bees under the microscope or displaying wing images on a special screen and measuring wings with dedicated rules were some of the early methods. These techniques were very time consuming $(27,60)$. Researchers started to use wing venation for evaluation of breed affiliation. Developing computer techniques opened new opportunities. The evolution of methods for the measurement of wings changed in time. Various high resolution readers, cameras and scanners as tools for wing imaging and software for the analysis of scanned images gained on popularity $(46,58)$. Automation of measurements facilitated analysis of wing parameters $(57,60)$. The "standard" morphometry based on forewing venation measured distances and angles between selected vein intersections. The growing geometric morphometry reads coordinates of all vein intersections and so differences between sub-species can be represented as vectors deforming the grid of the diagram. This method facilitates interpretation of results, contrary to the analysis of multiple distances and angles $(32,61)$. By comparing results provided by the both methods, researchers concluded that geometric morphometry classifies sub-species hardly better than the standard method but the standard method is sufficient for differentiating populations of bees. This geometric morphometry can be used for comparing new results to older ones (61). In addition, researchers argue that results provided by this method have to be compared to results of the evaluation of breed affiliation based on molecular methods (61). The increasingly accurate morphological description of populations of middleEuropean bees and the application of genetic analysis drives the improvement of methods for the protection of threatened populations of Apis m. mellifera.

\section{Characteristics of Apis m. mellifera based on genetic studies}

Introduction of DNA analysis methods has enabled verification of affiliation of populations with individual honey bee sub-species. A number of molecular methods were used, such as polymorphism of lengths of restrictive fragments (PCR- 
RFLP) of mitochondrial DNA (25), polymorphism of single nucleotides (SNP) (63), microsatellites (24) or allozymes (9).

The analysis of mitochondrial DNA (mtDNA) is useful for the determination of the level of hybridization while microsatellite sequences facilitate evaluation of the genetic diversity of populations $(4,24,43)$. Research has used microsatellite loci and mitochondrial DNA (mtDNA), including specifically cytochrome oxidase CO-I and CO-II using the DraI enzyme, or, sporadically, amplification of the gene of cytochrome $\mathrm{b}(\mathrm{CitB})$ and digestion of the gene with enzyme BglII $(16,21,23,24,42,43,45)$. MtDNA is inherited along the maternal line, so it is sufficient to analyze a single young working bee or a maggot. MtDNA does not yield to recombination and sub-species of the honey bee feature high polymorphism in terms of microsatellite sequences, so this has enabled the tracking and comparing of likely directions of propagation of genes in the long history of the evolution of bees, particularly during and after the last glaciation $(4,55,59)$. These methods (PCR-RFLP mtDNA and microsatellites) are applied very extensively in research serving the protection of bee gene resources because of the ease of analyzing, affordability (PCR-RFLP) and huge output of information (microsatellites) (41).

Because most of phenotypic features are determined by nuclear genes inherited after both parents, evaluation of bees from conservative bee cultures should use nuclear DNA markers. Microsatellites are one of the most extensively used genetic polymorphic Mendelian markers. They are based on the polymorphism of 9 microsatellite loci of the nuclear genome. One of the scientists (41) researched European honey bees of Apis $m$. mellifera species sampled from the Ural Mountains and the Volga River regions containing the largest reserves of the gene pool of the middle-European bee, consisting of approximately one thousand colonies of dark European honey bees. Research using microsatellites confirmed the large diversity of local populations. In many loci there is a clear geographic trend in changes of the frequency of alleles. Some alleles are close to being fixed in certain areas of the spread while in other locations they are extremely rare. This means the existence of diagnostic alleles for specific honey bee sub-species (41).

DNA analyses have made it possible to describe whole genomes, the genome map of honey bees, and to use more than 550 genetic markers for the description and comparison of populations of bees (56). Apis $m$. mellifera features smaller genetic variation than most of the other studied sub-species of the honey bee. In spite of this relative homozygosity, Apis m. mellifera has developed into a few ecotypes and can survive in strongly diversified climate conditions: from southern Spain to Sweden. All of these features are indicative of high evolutionary potential and ability to accommodate to local environments (24). Analysis of populations of the middle-European bee in their current habitats has shown various levels of propagation of foreign genes, coming mainly from Apis m. carnica sub-species: $0 \%$ in Norway, $14 \%$ in Denmark and approx. $30 \%$ in other countries (45).

\section{Protection of Apis m. mellifera in Europe}

Europe is becoming increasingly interested in the middle-European bee, specifically on the territories of its natural occurrence. Apis m. mellifera is exceptionally tolerant of unstable weather and well accommodated to difficult wintering. When used for commercial cross-breeding, the addition of genes from middleEuropean bees improves vitality, environmental flexibility and productivity of cross-breeds. According to the recent COLOSS research, local bees, such as Apis $m$. mellifera, live longest and they often perform best in terms of quietness and honey yield. Also, local bees are more immune to parasites and other pathogens (12, $28,37,62)$. It has been established that the effect of genotypes on the location plays a predominant role in the occurrence of diseases, such as the deformed wing virus associated with the epidemic of varroosis. The mean time of survival of sick local bees, such as Apis $m$. mellifera, is much longer than that of nonlocal bees. Local bees can have larger resources to contain parasites and pathogens owing to better accommodation to local climate and environment (37). Subsequent research confirmed that bee families with local queens (including middle-European bees) live longer - for instance by 83 days - than non-local ones (12). Furthermore, local bees were accommodated for wintering and harvested more honey than non-local bees: $24.5 \mathrm{~kg}$ vs. $22.7 \mathrm{~kg}$ (28). In addition, genotypes of local and non-local bee colonies have an important effect on their defensive behaviors (62). Subsequent research (37) has clearly revealed the effect of hybridization on bee behaviors: Apis m. mellifera is less aggressive in its natural environment. Also worthy of note is that, considering results of yet another research, the swarming of bees, such as middle-European breeds, was strongly affected by weather prevailing during the year, location and genotype (62).

Accordingly, more attention should be paid to the preservation of diversified genetic resources of honey bees, including of middle-European bees, throughout Europe. The establishment of areas of protection for endangered populations is one of the means of achieving this goal $(12,28,37,62)$. Today, middle-European bees are protected mainly in areas where this species evolved. European countries pursue various protection programs (53). Regardless of protection methods, all these programs aim to preserve characteristics of Apis $m$. mellifera as unchanged as possible, with retention of maximum genetic diversity of the species. One of the ideas consists of keeping local populations on islands providing physical isolation, such as La Palma (the Canary Islands), the Azores, Madeira, the Danish 
Tab. 2. Summary of the current number of colonies of Apis m. mellifera in the Nordic and Baltic countries. The asterisk denotes that the number of colonies for queen production and pairing can be smaller (47)

\begin{tabular}{|l|c|c|l|}
\hline \multicolumn{1}{|c|}{ Country } & Total colonies & $\begin{array}{c}\text { Colonies under effective } \\
\text { conservation work }\end{array}$ & \multicolumn{1}{c|}{ Conservation measures } \\
\hline Denmark & 300 & 200 & protected area on Laeso \\
Estonia & not available & not available & not available \\
Finland & 300 & 100 & private actions by beekeepers \\
Iceland & 0 & 0 & no Apis m. mellifera, only Buckfast bees \\
Latvia & 100 & 100 & the Latvian University of Agriculture works with private beekeepers' assistance, public support \\
Lithuania & not available & not available & not available \\
Norway & 8000 & 9000 & protected area in Vest-Agder and Rogaland counties, national support for beekeepers \\
Sweden & 2000 & 1000 & NordBi association since 1990, supported by the NordBi project \\
\hline
\end{tabular}

isle of Laeso (34) or the French Ouessant. France and, to some extent, England prefer programs based on contained conservative swarms while others, including Austria, Switzerland and Scandinavian countries, establish protected inland areas (22).

The idea of establishing such a conservative breeding area for middle-European bees in Norway dates back to the 1980s. In 1987, the Norwegian Department of Agriculture gave its consent and their program for protection of middle-European bees was launched 5 years later (30). There are a total of 45 thousand honey bee colonies in Norway. Out of these, 5 thousand -8 thousand, belonging to three populations, have been recognized as Apis m. mellifera colonies. There is an isolated breeding area in Vest-Agder and Rogaland counties, which includes Flekkefjord, Lund, Sokndal and Sirdal municipalities with a total area of 3.5 thousand $\mathrm{km}^{2}$. The breeding area is restricted such that only Apis. m. mellifera can be kept in the area (10). Migratory beekeeping in and out of the area is prohibited (66). It is prohibited to take bees or breeding material (queens, egg, larvae or semen) into the area. The number of beekeepers and colonies in the area has been steadily declining from 150 beekeepers with a total of 2.7 thousand colonies in 1985 to 30 beekeepers with 977 colonies in 2011, when a sugar tax was introduced. Thus, the population of these beneficial insects shrank as a result of the discontinuation of the financing of the protection of bees. The situation for the breeding population of the NBA (the Norwegian Beekeepers Association) is critical at the moment. This is due to several factors. Hybridization occurred at the NBA's mating station in 2005 but remained undiscovered until 2009. This resulted in a drastic culling of queens that were not found to be pure Apis m. mellifera. In 2010, an outbreak of European foul brood (M. plutonius) destroyed one third of the remaining breeding material of Apis. m. mellifera from the NBA's breeding program as well as most of the standing population of Apis. m. mellifera in the counties of Aust-Agder and Vest-Agder. The NBA is considering several measures to increase the breeding population, among them to import of material from other countries. Currently the NBA has taken measures to safeguard middle-European bees in
Norway against hybridization and encourage beekeepers to breed Apis m. mellifera (14).

Sweden is another Scandinavian country that has got involved in the protection of genetic resources Apis $m$. mellifera. Their program for protection of genetic resources of middle-European bees, financed in part by the Swedish Ministry of Agriculture, has been supported by NordBi for many years $(6,47,48)$. One of the goals of the program is to establish inland protection areas and mating grounds for middle-European bees. Around 2 thousand colonies are considered to be Apis. m. mellifera colonies. Half of them can be used as a gene reserve according to cubital and discoidal index measurements (Tab. 2). Around 100 colonies are used for breeding queens, which are used to establish the next generation. This means that less than $10 \%$ of the population is actively managed.

Finnish and Latvian beekeepers, in turn, base their activities for protection of Apis. m. mellifera on queens brought from Sweden. However, the population of dark bees in Finland is threatened with extinction. Finland's Apis $m$. mellifera was kept in many places in Finland until the 1970s. Apis m. mellifera was commonly crossed with Apis m. ligustica bees and many crossbred colonies existed at the end of $20^{\text {th }}$ century. The crossed Apis $m$. mellifera bees were particularly aggressive and this resulted in an unfavorable reputation. At the end of 1990 s more than $90 \%$ of the 40 thousand colonies found in Finland were Apis $\mathrm{m}$. ligustica and there was only one place in Muhos known to have Apis $m$. mellifera. This Väinö Mäki's population was taken to the apiaries of three private queen breeders and to the Finnish Beekeepers' breeding station at the end of the millennium. Later, the station was closed and now only one commercial Apis $m$. mellifera beekeeper is breeding Apis m. mellifera queens in South-West island Rymättylä (47). Some genetic material has been imported from Sweden to Finland during the last ten years and there has been some export of queens to Latvia. Latvia has been trying to preserve and protect its population of middle-European bees since 1971 in the Teicu National Park. Sixty bee families were bred at that time (47). Unfortunately, this population was lost as a result of winters and diseases. Apiaries of 
similar size have been restored under the aegis of the Latvian Agricultural University. In 2011, the Ministry of Agriculture supported the conservation work, comprising 60 colonies, with 8 thousand EUR.

Denmark is another country committed to protection of middle-European bees: the population of the "Danish brown bees of Laeso" (4). Based on genetic studies on this small population completed in 2003, only $35 \%$ of these bees were classified as "pure" middle-European bees. Denmark planned to increase the number of bees for breeding and for the selection of the "purest" genetic material. They selected 123 colonies of Apis m. mellifera for this purpose in 2007 (59) and located them on additional islands (Bornholm, Christianso and Endelave). Regrettably, this population is threatened by adverse effects of inbreeding and genetic drift (53).

Like in Denmark, 130 French volunteers, members of the beekeeper association established for the protection and selection of bees in Brittany, maintain a small native population on the Ouessant Island. Another preservation location in France, an inland one, is the Cevennes mountain range. The site is located in a national park in the southern part of the Central Massif, in the Lozere department. Here, the protection of native bees uses the traditional method of breeding them in "tree-hives" $(17,35)$. This apiary selects bees based on genetic studies that have screened out more than $97 \%$ of pure Apis m. mellifera specimens (17). In addition, the Landes region in south-western France researched its local ecotype of Apis m. mellifera distinctive for its annual cycle of brooding accommodated to the cycle of florescence of local vegetation (57). They concluded that their strategy for further protection of these bees required a combination of DNA tests, morphometric analysis and verification of annual cycles of brooding in bee families. The goal of these activities is to separate "pure" material from genes coming from other evolutionary lines than $\mathrm{M}$, particularly from line C.

Norway and Sweden form a region where Apis $m$. mellifera exists, but is threatened by other subspecies. Both countries have their own permanent populations in several locations. The Norwegian and Swedish populations have been shown to differ from each other, based on results from molecular analyses. In contrast, Finland, Denmark, Latvia and the Baltic countries only have a few Apis $m$. mellifera colonies left and the original populations are nearly extinct. Populations in these countries are extremely small. There is no natural gene flow between these colonies, but the exchange of breeding queens between beekeepers is increasing. The following country summaries are based on the interviews conducted during this project. For comparison see those which contain country data for Norway and Denmark (8).

Switzerland is another contributor of substantial resources for the protection of the gene pool of middleEuropean bees. This country maintains 130 thousand bee colonies including 10 thousand colonies of pure middle-European bees. Originally, the dark-colored Apis $m$. mellifera bee lived in the north of the Swiss Alps. After the $2^{\text {nd }}$ World Wars, as a result of the import of bees, mainly Apis m. carnica, and, more recently, also Buckfast, local populations of bees became hybridized. In the 1990s an Association of Friends of the Swiss Honey Bee (VSMB) was established to protect and breed local bees (22). They have taken two courses of action: maintain the breeding line and establish protected areas.

Their program for protection of genetic resources of Apis m. mellifera is based on the Best Linear Unbiased Prediction (BLUP) method and on DNA analyses for the elimination of cross-breeds from future generations. The other course of action consists of the establishment of protected areas. One of them, created more than 30 years ago in the Glarus canton, preserves 900 colonies. The other, established recently, is located in a $20 \mathrm{~km}$ long and $4 \mathrm{~km}$ wide valley of the National Park in the Val Mustair Biosphere Reservation Funds for continued protection of genetic resources of middleEuropean bees have been allocated for years 2015-2018 (Der Verein Schweizerischer Mellifera Bienenfreunde, VSMB - 2014).

From the perspective of the post-glacial expansion of Apis m. mellifera, Germany and Poland are the next regions to which the insect migrated. Germany protects the last of its native bees that resisted displacement by other breeds, namely Apis m. mellifera mellifera - the German "brown" bee, Apis m. mellifera lehzeni - the forest bee and Apis m. mellifera nigra - the black bee (46). Trained beekeepers, members of the Association for Preservation of Dark-colored Bees, introduce Apis $m$. mellifera queens to apiaries under the German program for the protection of genetic resources of this species. The breeding material has to be certified for origin and be verified for affiliation with middle-European bees. On the other hand, there are no specific criteria for selection of productive features. Poland was the first European country that took measures to protect Apis $m$. mellifera. The drop of the size of the population of the honey bee including the middle-European bee by approx. $50 \%$ was caused by the war (7). The present implementation of programs for protection of genetic resources of middle-European bees is monitored by the Ministry of Agriculture. Poland protects four lines of the middle-European breed: "M Augustów", "M Kampinos", "M North" and "M Asta". The programs are based on collaboration between leading apiaries and collaborating ones. Conservative breeding areas were established in the Augustów Backwoods (1976) and in the Kampinos Backwoods (1980) for the "M Augustów" and the "M Kampinos" lines, respectively $(31,44)$. The remaining two lines have no dedicated administrative areas but the organization of preserving queens is similar as for the former lines (31). The goals set for these lines are also similar: 
- for the "M Augustów" and "M Kampinos" lines:

1) maintain adequate local population sizes in the conservation areas;

2) reintroduce queens from conservative swarms to protected areas;

3) maintain adequate sizes of conservative swarms and preserve characteristics typical for these populations;

4) improve breeding features of the bees - honey yield, non-swarming, quietness - while preserving phenotypic and biological features characteristic for protected populations;

- for the "M North" and the "M Asta" lines: goals 3 and 4 above.

Apis m. mellifera has spread up to the Ural Mountains in Russia in the east where 300 thousand colonies are maintained in Bashkiria and 200 thousand in Perm Krai (29). Their affiliation with middle-European bees has been verified by DNA tests (COI-COII loci and 9 microsatellite sequences). Isolated populations are kept in the national parks of Shulgan-Tash and Bashkiria, in the southern part of the mountains in Altyn-Solok, in the central part of the mountains in Malinowyi Hutor, and in the Visherskii park on the north (29).

Measures taken by countries to protect black bees in Europe are supported by the International Association for the Protection of the European Dark Bee (SICAMM) established in 1995 by its eight original members including Poland (44). Today the Association groups most of European countries inhabited by middle-European bees or understanding the need for reintroducing them to their original habitats. Moreover, SICAMM has many NGO members: from individual researchers and beekeepers, regional and international apiarian organizations to research institutes. The organization focuses on any activities related to protection of Apis m. mellifera, supporting and promoting collaboration between apiary communities, researchers and governments, informing about the environmental importance of middle-European bees, as well as aid in sourcing political and financial support for protection of all ecotypes of the European dark bee.

Protection of Apis m. mellifera in Europe is necessary, considering the decreasing size, along with the threat of hybridization, of the population of middleEuropean bees. The paper demonstrates that the use of the morphometric evaluation and DNA analysis methods have made it possible to track and compare likely directions of propagation of genes in the long history of the evolution of bees. Moreover, these methods provide us with better insight into the ongoing processes. The current use of these methods is becoming increasingly helpful in protecting middle-European bee populations more effectively. This is because the application of both morphological analysis and the genetic method ensures accurate identification of breed affiliation, which is necessary for the attainment of goals of various programs for the protection of genetic resources of Apis m. mellifera. European programs for the protection of genetic resources of bees are based on the following two main paradigms: breeding of local isolated populations on islands and the establishment of protected inland areas for contained conservative swarms. Regardless of their methods of protection, all these programs aim at the preservation of the characteristics of Apis $m$. mellifera as unchanged as possible, with the retention of maximum genetic diversity of the species. Programs for the protection of genetic resources of Apis m. mellifera pursued in Europe over the last forty years create a real opportunity for preserving morphological characteristics of the middle-European bees. Moreover, constant monitoring of genetic and phenotypic changes in middle-European bees is a crucial factor in attaining the goal that consists of the preservation of the gene pool of Apis m. mellifera.

\section{References}

1. Alpatov $W$. W.: Biometrical studies on variation and races of the honey bee (Apis mellifera L.). Quarterly Review Biology 1929, 4, 1-58.

2. Alpatov $W$. W. Porody miedonosnoj pczeły i ich ispolzowanije w sielskom chozjajstwie. Sredi Prirodi 1948, 4, 1-70.

3. Alpatov $W$. $W$ : Über die Verkleinerung der Rüsellänge der Honigbiene von Süden nach Norden hin. Zoologischer Anzeiger 1925, 65, 103-111.

4. Arias M. C., Sheppard W. S.: Molecular phylogenetics of honey bee subspecies (Apis mellifera L.) inferred from mitochondrial DNA sequence. Mol. Phylogen Evol. 1996, 5, 557-566.

5. Arias M. C., Sheppard W. S.: Phylogenetic relationships of honey bees (Hymenoptera Apinae:Apini) inferred from nuclear and mitochondrial DNA sequence data. Mol. Phylogen and Evol. 2005, 37, 25-35.

6. Arvidsson I.: How to preserve and develop the native Black Bee in Sweden SICAMM Conference. Lanquart, Switzerland 2012, p. 21-23.

7. BanaszakJ., Czechowska W., Czechowski W., Garbarczyk H., SawoniewiczJ., Wiśniowski B.: Threats and perspectives of protection of Hymenoptera. Wiad. Entomol. 2000, 18, 177-211

8. Bouga M., Alaux C., Bieńkowska M., Büchler R., Carreck N. L., Cauia E., Chlebo R., Dahle B., Dall'Olio R., De la Rúa P., Gregorc A., Ivanova E., Kence A., Kence M., Kezic N., Kiprijanovska H., Kozmus P., Per Kryger P., Le Conte Y., Lodesani M., Murilhas A. M., Siceanu A., Soland G., Uzunov A., Wilde $J$ : : A review of methods for discrimination of honey bee populations as applied to European beekeeping. J. Apicult. Res. 2011, 50, 51-84.

9.Bouga M., Kilias G., Harizanis P. C., Papasotiropoulos V., Alahiotis S.: Allozyme variability and phylogenetic relationships in honey bee (Hymenoptera: Apidae: Apis mellifera) populations from Greece and Cyprus. Biochem. Gen. 2005, 43, 471-483.

10. Brown M. J. F., Paxton R. J.: The conservation of bees: a global perspective. Apidologie 2009, 40, 410-416.

11. Buttel-Reepen H.: Apistica. Beiträge zur Systematik, Biologie, sowie zur geschichtlichen und geographischen Verbereitung der Honigbiene (Apis mellifica L.), ihrer Varrietäten und der überigen Apis-Arten. Mitteilungen aus dem Zoologischen Museum in Berlin 1906, 3, 114-201.

12. Büchler R., Costa C., Hatjina F., Andonov S., Meixner M. D., Le Conte Y., Uzunov A., Berg S., Bienkowska M., Bouga M., Drazic M., Dyrba W., Kryger P., Panasiuk B., Pechhacker H., Petrov P., Kezić N., Korpela S., Wilde J.: The influence of genetic origin and its interaction with environmental effects on the survival of Apis mellifera L. colonies in Europe. J. Apicult. Res. 2014, 53, 205-214.

13. Cornuet J. M., Fresnaye J., Tassencourt L.: Discrimination et classification de populations d'abeilles a partir de caractéres biométriques. Apidologie 1975, 6, 145-187.

14. Dahle B.: Conservation efforts and status of Apis mellifera mellifera in Norway. BIBBA-SICAMM Conference. Llangollen, North Wales 2014, p. 26-28.

15. Demianowicz A.: Systematyka pszczół, [in:] Bornus L., ed. Hodowla pszczół. $2^{\text {nd }}$ (ed.) Poznań, Poland, PWRIL 1974, p. 43-51.

16. Diniz-Filho J. A. F., Fuchs S., Arias M. K.: Phylogeographical autocorrelation ofphenotypic evolution in honey bees (Apis mellifera L.). Heredity 1999, 83, 671-680.

17. Elie Y: Little brooks make great rivers. SICAMM Conference. Lanquart, Switzerland 2012, p. 34-36. 
18. Engel M. S.: The taxonomy of recent and fossil Honey Bees (Hymenoptera:Apidae; Apis). J. Hymenoptera Res. 1999, 8, 165-196.

19. Estoup A., Garnery L., Solignac M., Cornuet J. M.: Microsatellite variation in honey bee (Apis mellifera L.) populations: hierarchical genetic structure and test of the infinite allele and stepwise mutation models. Genetics 1995, 140, 679-695.

20. Franck P., Garnery L., Celebrano G., Solignac M., Cornuet J. M.: Hybrid origins of honeybees from Italy (Apis mellifera ligustica) and Sicily (Apis mellifera sicula). Mol. Ecology 2000, 9, 907-921.

21. Franck P., Garnery L., Loiseau A., Oldroyd B. P., Hepburn H. R., Solignac M., Cornuet J. M.: Genetic diversity of the honeybee in Africa: microsatellite and mitochondrial data. Heredity 2001, 86, 420-430.

22. Fried B.: Mellifera Conservation Project Val Müstair. SICAMM Conference. Lanquart, Switzerland: Mellifera. Proc. Reports 2012, p. 26-28.

23. Garnery L., Franck P., Baudry E., Vautrin D., Cornuet J. M., Solignac M. Genetic diversity of the west European honey bee (Apis mellifera mellifera and Apis mellifera iberica) I. Mitochondrial DNA. Gen. Select. Evol. 1998 30, 31-47.

24. Garnery L., Franck P., Baudry E., Vautrin D., Cornuet J. M., Solignac M.: Genetic diversity of the west European honey bee (Apis mellifera mellifera and Apis mellifera iberica) II. Microsatellite loci. Gen. Select. Evol. 1998, 30, 49-74.

25. Garnery L., Solignac M., Celebrano G., Cornuet J. M.: A simple test using restricted PCR amplified mitochondrial DNA to study the genetic structure of Apis mellifera. Experientia 1993, 49, 1016-1021.

26. Goetze G.: Die beste Biene. Verlag Lidloff, Loth\&Michaelis. Leipzig 1940, p. 64-198.

27. Guler A. A.: Morphometric model for determining the effect of commercial queen bee Osage on the native honeybee (Apis mellifera L.) population in a Turkish province. Apidologie 2010, 41, 622-635.

28. Hatjina F., Costa C., Büchler R., Uzunov A., Drazic M., Filipi J., Charistos L., Ruottinen L., Andonov S., Meixner M.D., Bienkowska M., Gerula D., PanasiukB. Le Conte Y., Wilde J., Berg S., Bouga M., Dyrba W., Kiprijanovska H., Korpela S., Kryger P., Lodesani M., Pechhacker H., Petrov P., Kezic N.: Population dynamics of European honey bee genotypes under different environmental conditions. J. Apicult Res. 2014, 53, 233-247.

29. Ilyasov A. R., Kutuev I., Petukhov A. V., Poskryakov A. V., Nikolenko A. G. Phylogenetic relationships of dark European honeybees Apis mellifera mellifera L. from the Russian Ural and West European populations. J. Apicult. Sci. 2011, 96, 67-76.

30. Jacob K.: Aspects of Beeswing morphology. $6^{\text {th }}$ SICAMM Conference. Læsø, Denmark 2004, p. 10-12

31. Jaszczyńska M.: Ochrona zasobów genetycznych pszczół. Wiad. Zootech. 2006, 44, 56-60

32. Kandemir I., Özkan A., Fuchs S.: Reevaluation of honeybee (Apis mellifera) microtaxonomy: a geometric morphometric approach. Apidologie 2011, 42 618-627.

33. Kotthoff U., Wappler T., Engel M. S.: Miocene honey bees from the Randeck Maar of southwestern Germany (Hymenoptera, Apidae). ZooKeys 2011, 96, 11-37.

34. Kryger P.: New threats for honeybee conservation on the Island of Laso. $5^{\text {th }}$ European Conference of Apidology. Halle an der Saale, Germany 2012, p. 134

35. Lehébel-Péron A., Schatz B., Dounias E.: Ethnobiological and ecological study of the black bee of the Cevennes bred in hollow chestnut trunks. Apimondia $41^{\text {st }}$ Congress. Montpellier, France 2009, p. 36

36. Maa T. C.: An inquiry into systematic of the tribus Apidini or honeybees (Hym). Treubia 1953, 21, 525-640.

37. Meixner M. D., Buchler R., Costa C., Andonov S., Bienkowska M., Bouga M. Filipi J., Hatjina F., Ivanova E., Kezic N., Kryger P., Le Conte Y., Panasiuk B., Petrov P., Routtinen L., Uzunov A., Wilde J.: Looking for the Best Bee - An Experiment about Interactions Letters to the Between Origin and Environment of Honey Bee Strains in Europe. American Bee Journal 2015, 155, 663-669.

38. Meixner M. D., Worobik M., Wilde J., Fuchs S., Koeniger N.: Apis mellifera mellifera in eastern Europe - morphometric variation and determination of its range limits. Apidologie 2007, 38, 191-197.

39. Miguel I., Iriondo M., Garnery L., Sheppard W. S., Estbona A.: Gene flow within the M evolutionary lineage of Apis mellifera: role of the Pyrenees, isolation by distanceand post-glacial re-colonization routes in the western Europe. Apidpologie 2007, 38, 141-155.

40. Murray T. E., Kuhlmann M., Potts S. G.: Conservation ecology of bees: populations, species and communities. Apidologie 2009, 40, 211-236.

41. Oleksa A., Burczyk J.: Markery DNA w hodowli zachowawczej rodzimych linii pszczoły miodnej. Wiad. Zootech. 2010, 48, 55-67.
42. Oleksa A., Chybicki I., Tofilski A., Burczyk J.: Nuclear and mitochondrial patterns of introgressioninto native dark bees (Apis mellifera mellifera) in Poland. J. Apicult. Res. 2011, 50, 116-129.

43. Oleksa A., Tofilski A.: Wing geometric morphometrics and microsatellite analysis provide similar discrimination of honey bee subspecies. Apidologie 2015, 46, 49-60.

44. Paleolog J.: Ochrona zasobów genetycznych zwierząt gospodarskich i dziko żyjących. Litwińczuk Z. (red.), PWRiL, Warszawa 2011, p. 195-211.

45. Pinto M. A., Henriques D., Chávez-Galarza J., Kryger P., Garnery L., Van der Zee R., Dahle B., Soland-Reckeweg G., De la Rúa P., Dall'Olio R., Carreck N. L., Johnston J. S.: Genetic integrity of the dark european honey bee (Apis mellifera mellifera) from protected populations: a genome-wide assessment using SNPs and mtDNA sequence data. J. Apicult. Res. 2014, 53, 269-278.

46. Rostecki P.: Zróżnicowanie morfologiczne linii hodowlanych pszczół środkowoeuropejskiej w rejonach zamkniętych, pasiekach zachowawczych i współpracujących. PhD, West Pomeranian University of Technology Szczecin, Poland 2009

47. Ruottinen L., Berg P., Kantanen J., Kristensen T. N., Prcebel A.: Status and Conservation of the Nordic Brown Bee: Final report. Nordic Genetic Resource Center 2014, p. 1-42.

48. Rustem A., Ilyasov R. A., Poskryakov A. V., Nikolenko A. G.: The population of the purebred dark European honeybees Apis mellifera mellifera in the Urals and the Volga region. NordBi-Aktuellt (Sweden) 2017, 1, 14-15.

49. Ruttner F.: Biogeography and taxonomy of honeybees, [in:]: Ruttner (ed.) Evolution. $1^{\text {st }}$ ed. Springer Verlag Berlin 1988, p. 3-278.

50. Ruttner F.: Biometrical-statistical analysis of the geographic variability of Apis mellifera L. I. Material and Methods. Apidologie 1978, 9, 363-381.

51. Ruttner F.: Graded geographical variability in honeybees and environment Pszczel. Zesz. Nauk. 1985, 24, 81-92.

52. Ruttner F., Milner E., Dews J. E.: The dark European honeybee Apis mellifera mellifera Linnaeus 1758. British Isles Bee Breeders Ass. Derby, UK 1990 p. 5-51.

53. Rúa P. De la, Jaffe R., Dall'Olio R., Muñoz I., Serrano J.: Biodiversity, conservation and current threats to European honeybees. Apidologie 2009, 40, 263-284

54. Schmitt T: Biogeographical and evolutionary importance of the European high mountain systems. Front Zoology 2009, 6, 1-10.

55. Schmitt T.: Molecular biogeography of Europe: Pleistocene cycles and postglacial trends. Front Zoology 2007, 4, 1-13.

56. Solignac M., Mougel F., Vautrin D., Monnerot M., Cornuet J. M.: A thirdgeneration microsatellite-based linkage map of the honey bee, Apis mellifera, and its comparison with the sequence-based physical map. Genom Biology 2007, 66, 1-14

57. Steinhage V., Schroder S., Lampe K., Cremers A. B.: Automated extraction and analysis of morphological features for species identification, [in:] MacLeod $\mathrm{N}$. (ed.): Automated Object Identificationin Systematics: Theory, Approaches, and Applications. CRC Press, Boca Raton, Florida 2007, p. 115-130.

58. Szymula J., Skowronek W., Bieńkowska M.: Use of various morphological traits measured by microscope or by computer methods in the honeybrr taxonomy. J. Apicult. Sci. 2010, 54, 91-97.

59. Taberlet P., Fumagalli L., Wust-Saucy A. G., Cosson J. F.: Comparative phylogeography and postglacial colonization routes in Europe. Mol. Ecology 1997, 453-464.

60. Tofilski A.: Automatic measurement of honeybee wings, [in:] MacLeod N (ed.): Automated Object Identification in Systematics: Theory, Approaches and Applications. CRC Press, Boca Raton, Florida 2007, p. 289-298.

61. Tofilski A.: Using geometric morphometrics and standard morphometry to discriminate three honeybee subspecies. Apodologie 2008, 39, 558-563.

62. Uzunov A., Costa C., Panasiuk B., Meixner M., Kryger P., Hatjina F., Bouga M., Andonov S., Bienkowska M., Le Conte Y., Wilde J., Gerula D., Kiprijanovska H., Filipi J., Petrov P., Ruottinen L., Pechhacker H., Berg S., Dyrba W., Ivanova E., Büchler R.: Swarming, defensive and hygienic behaviour in honey bee colonies of different genetic origin in a pan-European experiment. J. Apicult. Res. 2014, 53, 248-260.

63. Whitfield C. W., Behura S. K., Berlocher S. H., Clark A. G., Johnston J. S. Sheppard W. S., Smith D. R., Suarez A. V., Weaver D., Tsutsui N. D.: Thrice out of Africa: ancient and recent expansions of the honey bee, Apis mellifera. Animals Science 2006, 314, 42-645.

64. Wilde J.: Hodowla pszczół. Systematyka pszczoły. PWRiL, Poznań 2008, p. 19-37.

65. Wilde J.: Pszczelnictwo. Systematyka pszczoły. Wyd. Prom. Albatros, Szczecin 1998, p. 67-110.

66. Zayed A.: Bee genetics and conservation. Apidologie 2009, 40, 237-262.

Corresponding author: Dr hab. Beata Madras-Majewska, Assist. Prof., ul. Nowoursynowska 166, 02-787 Warszawa, Poland; e-mail: beata madras majewska@sggw.pl 